\title{
Poverty in Gombe State: Causes, Manifestations and Strategies of Alleviation
}

\author{
Babayo Sule ${ }^{1}$, Usman Sambo ${ }^{2}$ \\ ${ }^{1}$ Department of Political Science, Federal University of Kashere Gombe, Gombe State Nigeria \\ 2Department of Public Administration, Yobe State University Damaturu, Nigeria \\ Email: babayosule@gmail.com, ussambo2@gmail.com
}

\begin{abstract}
:
Poverty is a phenomenon that is affecting our society negatively as its scorch keeps on biting harder despite the rate in which revenue is rising in Nigeria. Gombe State is one of the states that is categorized among the poorest in Nigeria for a decade. Poverty is affecting the socioeconomic and political wellbeing of Gombe State in many perspectives. This paper examined the issues and perspectives of poverty in Gombe State particularly the causes, manifestations and strategies of alleviation. The work used primary and secondary sources of data collection where some respondents were selected through a simple random sampling for questionnaire administration and other key stakeholders were identified for an in-depth interview. The secondary source involves documents such as books, reports, journals and internet sources. The data obtained were presented and analysed using statistical tools such as tables and charts where applicable. The paper concludes that; poverty is caused mainly due to poor government's macro and micro economic policies and that poverty level in Gombe State has reached an unbearable index of 74.6 $\%$ according to the research and also the National Bureau of Statistics report which ranked the State the third most poor State in the country in 2015. The paper recommends that, for poverty to be alleviated in Gombe State, there should be a comprehensive and integrated approach via well designed policies such as Conditional Cash Transfer, development of agricultural sector, small scale industrialisation and youth empowerment schemes. It is also recommended that some models like Malaysian social investment and empowerment should be considered.
\end{abstract}

\section{Keywords:}

NAPEP; poverty; poverty perception index; poverty alleviation; strategies

\section{Introduction}

Poverty amidst plenty is the World's greatest challenge and it's expected to be fought with passion and professionalism by all nations. Poverty is the major challenge facing our nation today. According to a 2004 survey by the Federal Bureau of Statistics, 54\% of Nigerians lives in poverty. Though this figure represents a reduction from the $65.5 \%$ that was given in 1996, it is still an unacceptable high percentage (Kpakol, 2007). By 2006, the percentage of those living in poverty rose to $64.4 \%, 70.6 \%$ in 2007, and 70\% in 2010 and 2012 respectively (UNDP 2012 and NBS 2012). The percentage of those living in poverty in Nigeria keeps on rising from $70 \%$ to $72.6 \%$ in 2017 and by 2018, Nigeria was declared the headquarters of poverty in the world ahead of India and China (National Bureau of Statistics 2018).

Nigeria is one of the countries that are noted for the prevalence of absolute poverty in all its characteristic features. Poverty in these countries is massive, pervasive and chronic, engulfing a large proportion of the society. Concern about poverty in most of these countries, including Nigeria is great (Orji, 2008). Gombe State is one of the poorest states in Nigeria having a poverty level of $74.6 \%$ in 2015 emerging as the third poorest according to a data released by National Bureau of Statistics (NBS, 2015). This work examined the nature and dimensions of 


\section{Britain International of Humanities and Social Sciences (BIoHS) Journal \\ ISSN: 2685-3868(Online), 2685-1989(Print) \\ Vol. 2, No. 3, October 2020, Page: 706-720}

poverty in Gombe State, causes, manifestations and strategies of alleviation. The State is one of the least populated with low level of revenue generation but higher economic opportunities in terms of geographical location, land and business chances.

\section{Review of Literatures}

\subsection{The Concept of Poverty}

The issue of poverty was first given much attention by classical political economists in their attempt to explain economic growth, development and international trade. Adam Smith (1759) in his book "An Inquiry into the Wealth of Nations" identified poverty as a psychic pain which distresses the poor. This in turn causes real hardship, the deprivation of goods per se hardly entered the picture. He stressed that what oppressed a man in poverty was not a lack of physical comfort or health but a sense of social isolation and inferiority (Smith, 1759:170). Sen (1997) believes that poverty is the worst form of human deprivation and can only be understood as manifest from the life one lead and that, it is anti-progress and anti-development. In his words, poverty is, in many ways, the worst form of human deprivation (Sen., 1997:5).

Mahbub ul haq (1999:2), identifies poverty as a bomb which was never defused in high growth periods, and can easily explode in a period of slow growth, high inflation, rising unemployment and deteriorating social services. Poverty mis-governance, and unevenly distributed growth are today locked in a fatal embrace. Mahbub ul Haq (1999) opines that poverty of opportunity is the problem and not poverty itself because poverty is a result of poverty of opportunity. It is a form of deprivation that creates inequality which requires an address urgently because it is possible to do so with sincerity of purpose. There is an increasing concern that economic growth is not leading to declining poverty and inequality in most developing countries and the gap between the rich and poor countries is widening (Sachs, 2015:7).

The most affected region in the world by poverty incidence is Sub-Saharan Africa. The pervasive and chronic nature of poverty in Sub-Saharan Africa created a wider vacuum for infrastructure and human development projects (Estache \& Wodon, 2014). Growth and economic recovery have been witnessed in Sub-Saharan Africa but the issue is the nature in which these growths and economic progress failed to translate into welfare of the inhabitants of these countries (Arnt, McKay \& Tarp, 2016). Nigeria is one of the countries in Sub-Saharan Africa which is paradoxically poor despite being rich with abundant natural mineral resources endowment and human resource availability in addition to robust geographical landscape suitable for agricultural and industrial activities. Nigeria is rich being the tenth largest oil producing country and with possession of diverse rich mineral resources in addition to human resources with a population that is also seventh in the world currently estimated at 200 million, majority of Nigerians amounting to $70 \%$ lives in poverty spending less than USD 2 per day because of many failed policies and lack of political will to initiate genuine policies that will extricate many individual households from poverty into a better and prosperous life (National Bureau of Statistics 2017 and Human Development Report 2017, UNDP).

\subsection{Causes of Poverty}

The causes of poverty in developing countries have been debated. According to Dependency scholars like Rodney (1972), Onimode (1983), Offiong (1980), the poverty of Africa and Nigeria in particular is rooted in the unequal relationship developed between the continent and country and the industrialised capitalist countries via the slave trade, the legitimate trade, colonialism and neo-colonialism. The World Bank however associated poverty in Nigeria 
with mainly macroeconomic problems including fall in oil revenues, excessive borrowing, drift and decline in wages (Fwatshak, 2006). Orji (2008) shares the same view with Fwatshak (2006) on the causes of Nigerian poverty. Magaji (2005) presented a similar analysis like that of Orji but with much emphasis on neo-colonial Nigeria (Magaji,2005:39).

Nwagbara (2001) sees culture impoverishment via globalisation as a major cause of poverty. To him, cultural impoverishment is yet another form of poverty inflicted on societies through the influence of globalisation. The view by Nwagbara (2001) is also supported by Mansaray \& Mansaray Jnr (2020). Ijaiya (2007:47) reiterates that the factors that cause poverty include: (i) structural causes such as limited resources, lack of skill, location disadvantage and other factors that are inherent in the social and political set up; (ii) the transitional causes that are mainly due to structural adjustment reforms and changes in domestic economic policies that may result in price changes, increase unemployment and others. Natural calamities such as wars, environmental degradation, also include transitory poverty.

Aliyu (2008) also attributes the causes of poverty in Nigeria to the structural political, socioeconomic and cultural factors such poor macroeconomic policies, declining performance of manufacturing sector, increasing foreign debt, mismanagement of resources and poor implementation of government policies.

The same views presented by Aliyu (2008) were also analysed by Sagagi (2008), Maikaba (2008), Edoh (2003), Ajakaiye (2002), Olofin (2008), Anyanwu (1997), and Ajegi (2002) as the major causes of poverty in Nigeria. Udegbunam (2006) views the role of unemployment in causing poverty. In his critical analysis of unemployment in Nigeria. Udegbunam explains that, nearly $40 \%$ of the working population in Nigeria is either jobless or underemployed. He further expanded his analysis on the basis of unemployment among the graduate with formal education. In his study, $1.9 \%$ of NCE holders are unemployed, $52.2 \%$ of ND and HND, $39.5 \%$ of B.sc and $4.9 \%$ of M.Sc and $\mathrm{PhD}$ holders. In all, the general impact of unemployment is poverty in Nigeria.

\subsection{Manifestations of Poverty}

Poverty manifested in many ways. Statistics on poverty in Nigeria revealed that Nigeria's Human Development Index in 1999 was only 0.416 with nearly $70 \%$ of its population of about 110 million living below the poverty line (spending less than a dollar per day), as against 15\% at independence in 1960. National average indicates that life expectancy at birth stands at 51 years; nearly $40 \%$ of the children below the age of 5 years suffer malnutrition, over $50 \%$ of the population lacks access to safe drinking water, and only $40 \%$ of the population is literate with only about 35\% of the population living in urban areas (Dandago, 2008:38-39).

Rural dwellers are among the hardest hit by these entire statistics, with about $70 \%$ of their population having no access to portable water, health care facilities or electricity, amongst other vital facilities necessary for decent living. The statistics disclosed that by 2003 , the number of poor people in Nigeria has doubled over the last two decades, during which the country received over $\$ 300$ billion in oil and gas revenues.

Here, it is not the increasing rate of poverty from 1999 and declining standard of living that is alarming, the most annoying thing is the increasing oil revenue and economic growth which failed to commensurate with the standard of living of an average Nigerian. Nigeria within sixteen years from 1999 to 2016 earned a huge oil revenue amounting to N77.348 (\$215, 027, 440, 000 billion) trillion (Central Bank of Nigeria, 2017) just from the petroleum industry but the Nigerian government has been unable to utilise the funds to improve the lives of its citizens. 
This has been one of the explanations why the poverty level increased in the country from 1999 to 2017 in contrary to the increasing revenue. The National Bureau of Statistics (2017) revealed that Nigeria earned approximately between 1999 to 2017 equivalent to $\$ 800$ billion in oil revenue along.

Similarly, Nigeria's budget rose from 1999 to 2017 steadily in a significant portion. For instance, in 1999 , Nigeria budgeted $\$ 13.6$ billion, $\$ 14.7$ billion in 2006, $\$ 18.7$ billion in 2007, $\$ 21.1$ billion in 2008, $\$ 22.8$ billion in 2009, $\$ 29.3$ billion in 2010, $\$ 31.8$ billion in 2011 and $\$ 31.9$ billion in 2016. This increase in national budget does not translate into poverty reduction policies. In the period between 1999 to 2017, there were series of policies and programmes to alleviate poverty but the policies did not impact positively on the common man in Nigeria. In the year 2000, a poverty alleviation programme was introduced called Poverty Alleviation Programme (PAP) but as early as 2001, the Federal Government declared the policy as a failure and introduced another one, the National Poverty Eradication Programme (NAPEP) in 2001 targetted at eradicating poverty by the year 2010. The policy failed in its approach and implementation making poverty incidence in Nigeria to increase incidentally in the year 2010, 2011 up to 2017 from $24.6 \%$ in 1999 to $54.3 \%$ in $2001,63.4 \%$ in $2004,68.9 \%$ in $2007,70 \%$ in $2010 \%, 70 \%$ in 2012, 2013, 2014 and 2017 respectively. Other economic development policies failed to take into account the integration of masses-oriented policies for poverty reduction such as the National Economic Empowerment Development Strategy (NEEDS) initiated in 2003, Seven Point Agenda in 2007 and other related economic development policies.

The above period which recorded an oil boom and an increased revenue also recorded the higher incidence of poverty index in Nigeria as revealed below.

Table 1. National Poverty Level $1980-2017$

\begin{tabular}{cc}
\hline Year & Poverty level \% \\
\hline 1980 & $27.2 \%$ \\
1985 & $46.3 \%$ \\
1992 & $42.7 \%$ \\
1996 & $65.6 \%$ \\
2004 & $54.4 \%$ \\
2007 & $70.6 \%$ \\
2010 & $70 \%$ \\
2012 & $70 \%$ \\
2013 & $63.4 \%$ \\
2014 & $61.2 \%$ \\
2015 & $62.6 \%$ \\
2016 & $70.6 \%$ \\
2017 & $71.6 \%$ \\
2018 & $72.4 \%$ \\
\hline
\end{tabular}

Source: National Bureau of statistics 2018.

\subsection{Strategy of Poverty Alleviation}

There are many suggested strategies for poverty alleviation which can be implementable in Nigeria. Sen (1999) observes that poverty can be reduced through an integrated approach where mankind can be free, all opportunities are harnessed for utilisation and inequality gap is drastically reduced while employment is generated accordingly. In another view, Mahbub U1 Haq (1999) identified that it is not the real poverty that is the problem but the poverty of ideas and deprivation. If the poor will be empowered and motivated, he can succeed in working towards extricating himself from poverty through effective utilisation of the chances offered. 
There are other models that Nigeria can adopt in general and Gombe State in particular to be utilise as strategies for poverty eradication. The first model is the Brazilian Bolsa Familia or the Conditional Cash Transfer (CCT) in which the poor are integrated in social investment programmes including education, health and job creation which was introduced by Inacio Silva $\mathrm{Da}$ Lula and which has succeeded in removing about $29 \%$ of the Brazilians from poverty line in just 10 years (Sule, 2014). Another strategy that can be borrowed is the Malaysian model of economic empowerment, gender empowerment and education revolution which miraculously turned the country into an economic power in Asia Pacific, in the Asian continent and in the world at large (Sule, 2014) and Indonesian Model (Popovic, Samouilidou, Popovic \& Dolga, 2020).

\subsection{Framework of Analysis: Vicious Circle of Poverty}

Ragnar Nurkse in a book titled "Problems of Capital Formation in Underdeveloped Countries" theorised poverty in a model called "Vicious circle of poverty". According to Nurkse"In discussion of the problem of economic development, phrase that crops up frequently is the vicious circle of poverty" (1967: 4).

Vicious circle of poverty implies a circular constellation of forces tending to act and react upon one another in such a way as to keep a poor country in a state of poverty. Particular instance of such circular constellations are not difficult to imagine, for example, a poor man may not have enough to eat, being underfed his health may be weak and being physically weak, his working capacity is low which means that he is poor, a situation of this sort, relating to a country as whole can be summed up in trite proposition hence: a country is poor because it is poor (Nurkse 1967: 4).

Jhingan (2007: 31-32) further developed and expanded Nurke's theory of Vicious Circle of Poverty, that the basic vicious circle stems from the fact that in less developed countries, total productivity is low due to deficiency of capital market and low investment on human capital, economic backwardness and underdevelopment. This is illustrated below:
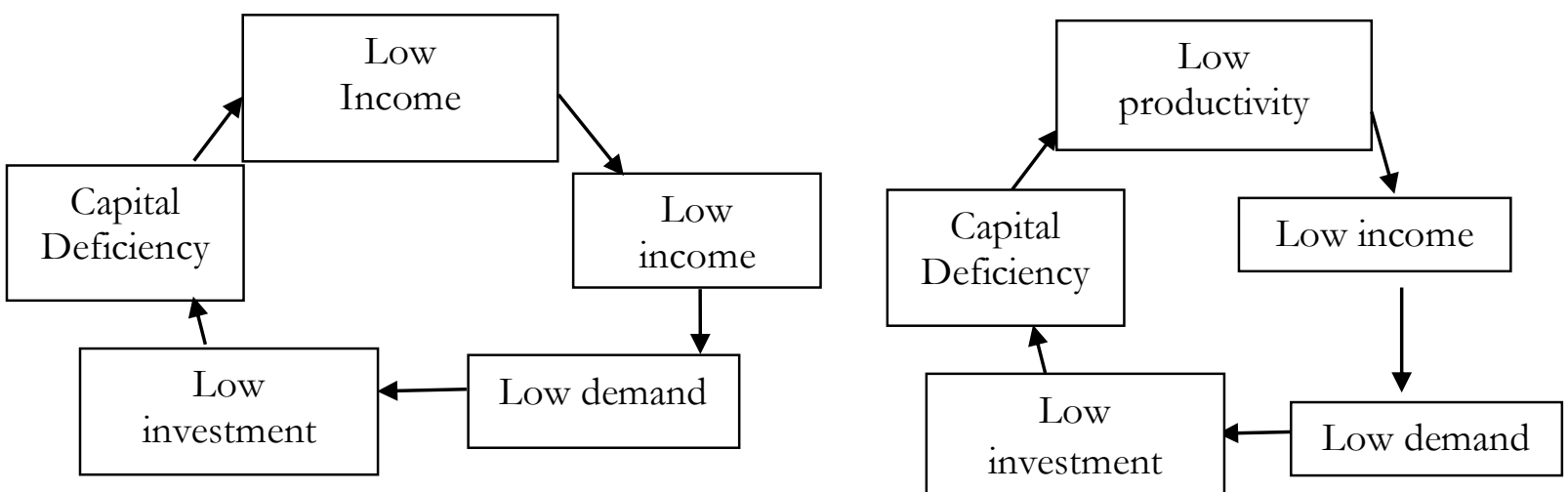

Figure 1. Showing the Circular Flow of Poverty in a Society Source: Jhingan, 2007

A complement of the vicious circle of poverty envelops underdeveloped human natural resources which is dependent upon the productive capacity of the people in the country. If the people are backward and illiterate, lack in technical skill, knowledge and entrepreneurial activity, the natural resources will tend to remain unutilized, and leading to underutilization or even misutilisation. This is explained below. 


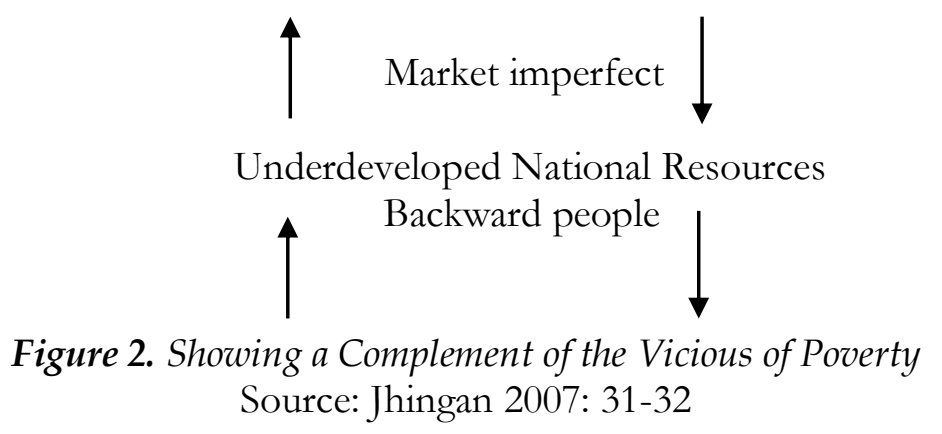

The Vicious Circle of Poverty can clearly explain poverty and poverty eradication policies in Nigeria. Even though some scholars; Myrdal (1974), Ake (1996) and Somasundara (2010) do not absolutely subscribe to the view that poor are likely to remain poor because it is intergenerational. These scholars agreed with Nurkse (1967); Jhingan (2007); and Hill (1985) that, poor are in vicious circle of poverty and are likely to remain so if the government policies are not directed towards genuine National Development.

The theory is capable of explaining the situation in Gombe State because the persistent cause of poverty is associated with low income, low savings and low investment which is perpetually keeping the poor in continuous poverty despite several efforts by the government to alleviate the menace such as National Poverty Eradication Programme (NAPEP). A good policy should seek to eradicate poverty because reduction will amount to little changes or the resurgence of that phenomenon which is exactly what the theorists are postulating that the poor are likely to remain in poverty if the policy makers are not serious. Payment of N3,000 allowances monthly under the NAPEP where the training is not absolutely practiced will not lead to high income, high demand, high supply, high saving and increase productivity. Instead, the process adopted by NAPEP may lead to low attainment of income, supply, demand, and other variable factors which are the ingredient of keeping poor in vicious circle of poverty.

\section{Methodology}

The research used both primary and secondary sources of data. The primary data is categorised into two. The first is the questionnaire administration with some selected respondents. Gombe State is divided into eleven local government areas with three geo-political zones as Gombe North, Gombe Central and Gombe South. The total population of the study which is Gombe State is estimated at 3.6 million according to 2006 population census projection. In each of the geo-political zones, one local government was identified and selected for data collection based on the report of the NBS 2004 of the poorest in each zone. In Gombe North, Dukku Local Government was selected out of Gombe, Kwami, Dukku, Funakaye and Nafada. In Gombe Central, Akko was selected between the Akko and Yamaltu/Deba. In Gombe South, out of Balanga, Billiri, Kaltungo and Shongom, Shongom was selected. The total number of respondents from each of the local government selected were 200 respondents based on equal proportion. The criteria for the selection was simple random sampling where questionnaires were indiscriminately distributed. The total number selected therefore was 600 . The questionnaires were designed using structured or open-ended. 
Table 2. Number of Respondents Selected from the Chosen Area of Study

\begin{tabular}{lll}
\hline S/No & Local Government & Number of Respondents \\
\hline 1. & Akko & 200 \\
2. & Dukku & 200 \\
3. & Shongom & 200 \\
4. & Total & 600 \\
\hline \multicolumn{2}{c}{ Source: Field Survey 2017. }
\end{tabular}

However, out of the total of 600 questionnaires distributed, only 527 were returned as indicated in the figure below.

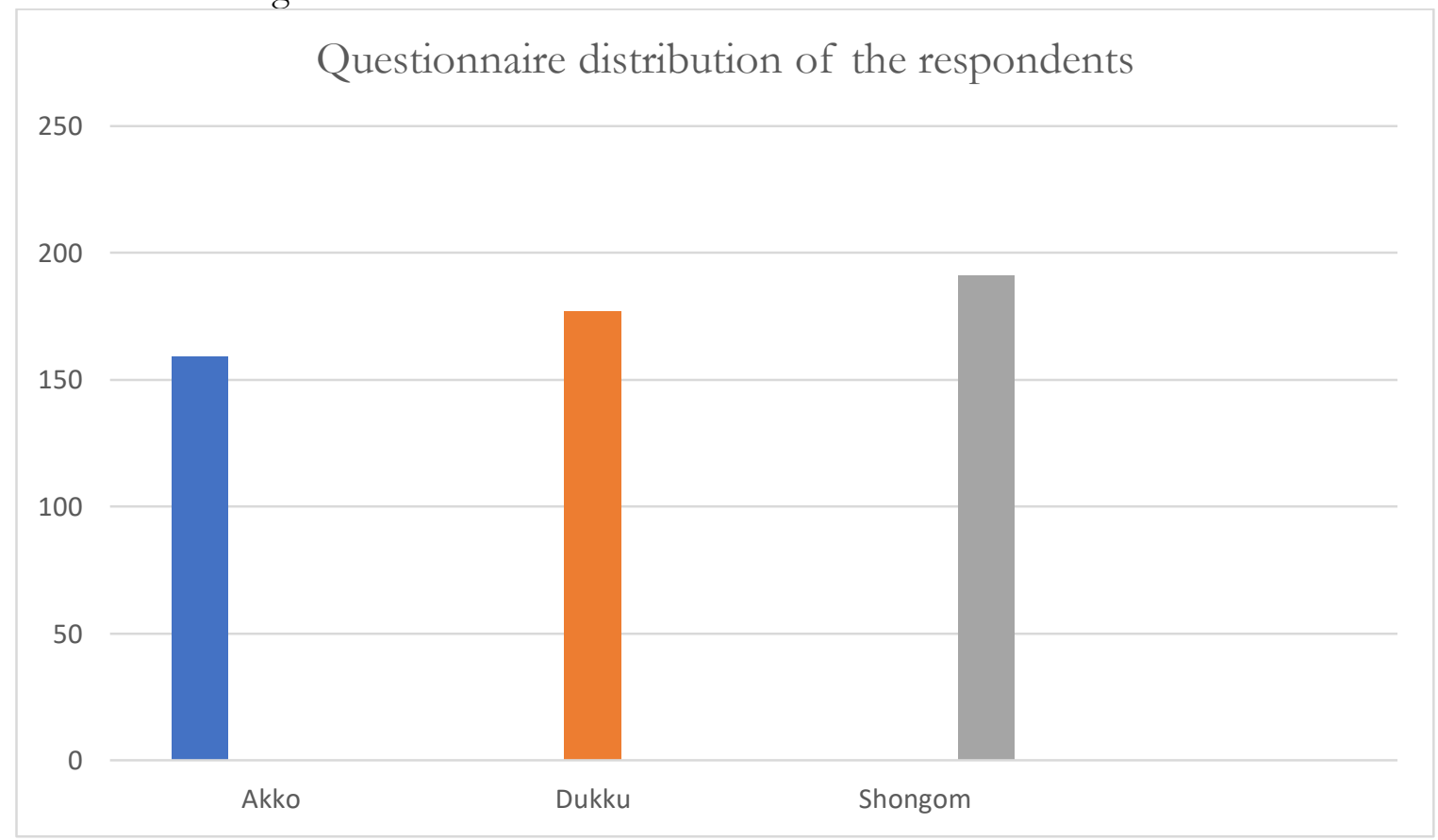

Figure 3. Total Number of Returned Questionnaires

Source: Field Survey 2017.

The other primary source is the interview with some key stakeholders among the policymakers and in this regard, two senior officials were selected from the National Poverty Alleviation Programme (NAPEP) Gombe office, two senior officials from Gombe State Bureau of Statistics and one senior official from the Gombe State Ministry of Economic Planning for an in-depth personal interview on the subject matter. The secondary sources consist of the documents that were consulted on the existing literature such as books, journal articles, reports from organisations and agencies and internet sources. The data obtained from the field were distributed and discussed using the simple statistical techniques such as tables and charts where necessary.

\section{Discussion}

\subsection{Causes of Poverty in Gombe State}

There are variant views on the causes of poverty in Gombe State as suggested by many of the respondents in their various responses. Their responses were summarised from the various questions that were asked and presented in tabular form below. 
Table 3. Summary of Respondents' Views on the Causes of Poverty in Gombe State

\begin{tabular}{llll}
\hline S/No. & Causes & Agreed & Disagreed \\
\hline 1. & Poor Macroeconomic Policies & $497(94.31 \%)$ & $30(5.69 \%)$ \\
2. & Corruption & $427(81.02 \%)$ & $100(18.98 \%)$ \\
3. & Mismanagement & $513(97.34 \%)$ & $14(2.66 \%)$ \\
4. & Low level of education & $439(83.30 \%)$ & $88(16.70 \%)$ \\
5. & Inequality & $487(92.41 \%)$ & $40(7.59 \%)$ \\
6. & Low level of income & $511(96.96 \%)$ & $16(3.04 \%)$ \\
7. & Attitude & $467(88.61 \%)$ & $60(11.39 \%)$ \\
8. & Low revenue generation capacity & $439(83.30 \%)$ & $88(16.70 \%)$ \\
9. & Absence of welfare and social investment & $514(97.53 \%)$ & $13(2.47 \%)$ \\
\hline
\end{tabular}
Source: Field Survey 2017

Additionally, the informants that were interviewed also supported the above views of the respondents in their different submissions which are summarised as follows. They have narrated that poverty in Gombe State is caused by several multiple factors top among which include absence of well-designed programmes genuinely targetted for social investment and welfare, bribery and corruption of the public office holders, poor policies, mismanagement of public resources, low level of opportunities, poor attitude of laziness and lack of productivity of the youth particularly and low level of education especially technical and vocational education for self-reliance. The informants further disclosed that lip services from politicians without corroborating it with action is another problem or simply lack of political will.

\subsection{Manifestations of Poverty and its Effects in Gombe State}

The incidence of poverty keeps on increasing in Gombe State instead of reducing. From the period of the introduction of NAPEP, a significant rise in figure of those identified to be poor in Gombe State is enough to show that, the policy is not the solution to poverty eradication or rather, implementation process. For instance, in 1996, those in poverty level in Gombe State was reported to be $56.4 \%$. In 2001, during the period of the introduction of NAPEP, the figure rose to $70.6 \%$. The figure however fall to $64.2 \%$ in 2004 and rose to $70.4 \%$ in 2007 , But, the percentage increase to $72.4 \%$ in 2010 and $72.6 \%$ in January 2013 as reported by Ministry of Economic Planning in Gombe State. The State emerged as the third poorest in 2015 with a percentage of $74.6 \%$ according to National Bureau of Statistics. This is indicated in the table below.

Table 4. Poverty Perception Index in Gombe State 1996 to 2015

\begin{tabular}{ll}
\hline Year & Percentage \\
\hline 1996 & $56.4 \%$ \\
2001 & $70.6 \%$ \\
2004 & $64.2 \%$ \\
2007 & $70.4 \%$ \\
2013 & $72.6 \%$ \\
2015 & $74.6 \%$ \\
2016 & $72.4 \%$ \\
2017 & $72.6 \%$ \\
2018 & $73.6 \%$ \\
\hline
\end{tabular}

Source: National Bureau of Statistics (2018) as compiled by the author

The above analysis clearly shows that, poverty is increasing which means policies on ground should be revisited or even replaced if there is need for prompt concern towards poverty eradication in Gombe State and Nigeria in general. 
The level of deprivation is varied ranging from healthcare services, education, and provision of infrastructure. Some sections of the population may be better off in terms of income but accessibility to education, proper healthcare service and infrastructure is deprived from them. This means that, poverty eradication by skills acquisition alone if not accompanied by other indicators of a decent living, such as education, healthcare services, infrastructure will not succeed. There is need for a more comprehensive programme. It is observed that, some people are pushed into poverty by number of dependents. Even if the policies of poverty eradication are successful in self-empowerment, poverty eradication is difficult if the dependents are not catered for.

One of the persistence reasons why poverty is increasing in Gombe State despite poverty eradication policies such as NAPEP is; low level of income of individuals. The implication of low income is low saving, low investment, low demand and low supply. All these economically disempowered people. To eradicate poverty using a policy like NAPEP and CAP will not address these economic issues but rather, it will continue in this way for many generations. Gombe State recorded a high rate of poverty and inequality according to the statistics below.

Table 7. Poverty and Inequality indicators across states in 2007 per capita income by state (US\$)

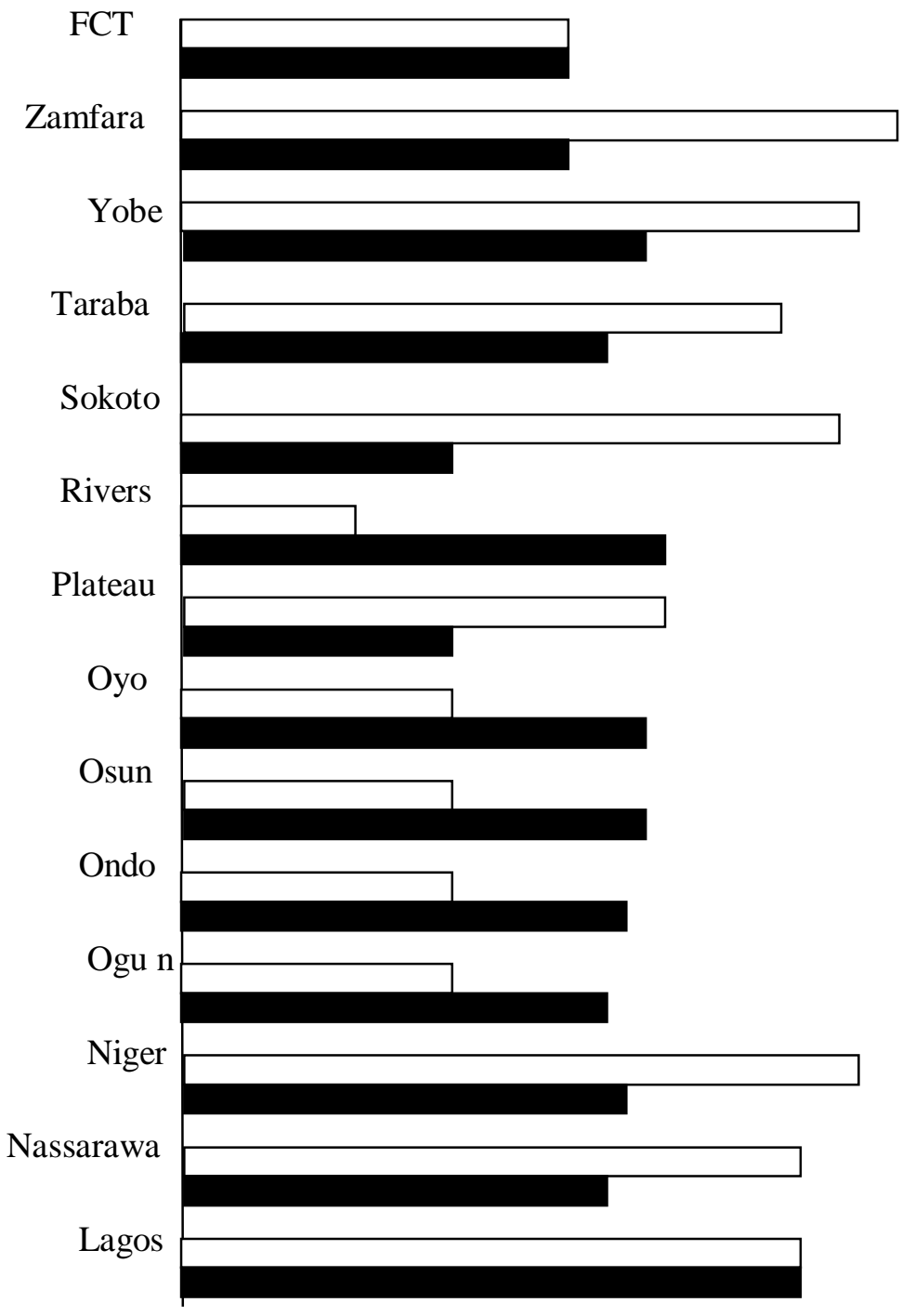




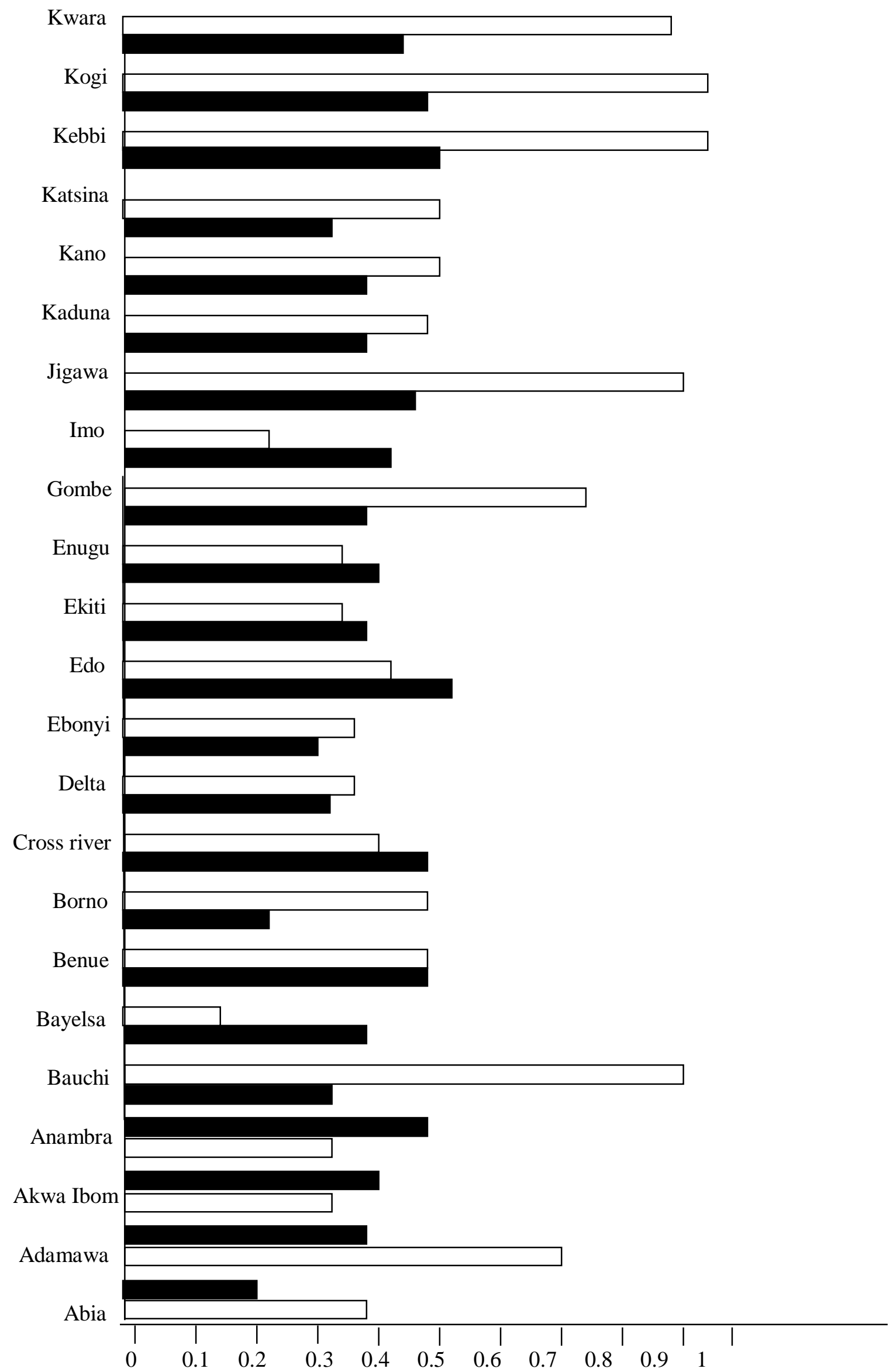

Source: Human Development Report in Nigeria 2008 - 2009 
Thus, the above table indicated that Gombe State is one of the states with highest incidences of poverty and inequality as discussed in the Theory of Vicious Cycle of Poverty where low income, low wages all lead to low demand and supply and vice versa leading to a perpetual poverty and its increase continuously. Sule, Umar \& Yahaya (2019) reported that despite the various poverty alleviation programes in Gombe State such as Capacity Acquisition Programme (CAP), the level of poverty in the State keeps on rising due to poor implementation, insincerity of politicians and politicisation of the process. Additionally, Sule \& Umar (2019) reported again in another study that poverty alleviation in Nigeria in general is a cosmetic political designed to secure cheap political goal and the support of the populace during elections mostly.

\subsection{Strategies of Poverty Alleviation in Gombe State}

The respondents were asked on the strategies that can be adopted to alleviate poverty in Gombe State and they responded in the following way. Their responses were summarised below.

Table 8. Summary of the Respondents Views on the Strategies of Poverty Alleviation in Gombe State

\begin{tabular}{lll}
\hline S/No. & Strategies Suggested/Responses & Frequency \\
\hline 1. & Initiation of social investment programmes & $487(92.41 \%)$ \\
2. & Proper management of scarce resources & $498(94.50 \%)$ \\
3. & Bridging the gap of inequality & $507(96.20 \%)$ \\
4. & Sustained vocational training and empowerment & $503(95.45 \%)$ \\
5. & Employment generation & $501(95.01 \%)$ \\
6. & Diversified means of revenue generation & $413(78.37 \%)$ \\
7. & Improved education and healthcare & $493(93.55 \%)$ \\
8. & Adoption of a workable external model & $421(79.87 \%)$ \\
\hline
\end{tabular}

Source: Field Survey 2017.

In a similar, the selected informants also share the same view with the respondents where they expressed in their various views that there are several strategies that can used to alleviate poverty in Gombe State. They expressed that there is a need for the State Government to come up with some substantive measures to alleviate poverty in the state and these measures can include improvement in the quality and affordability of education and healthcare services, designing of social investment programmes, intensive vocational training, sustained employment generation, adopting models of Brazilian Conditional Cash Transfer or Bolsa Familia or the Malaysian model of empowerment and welfare and a sincerity of purpose by the policymakers.

\section{Conclusion}

It can be deduced from the research that poverty increase in the whole of Nigeria and Gombe state. This is because the rate of poverty incidence keeps shooting up despite many attempts by Nigerian government to curb it. The most nagging issue in Nigeria is that, while revenue keeps on increasing accruing to oil windfall in 2003, the revenue incurred did not translate into any positive development to the masses like poverty eradication, provision of infrastructures.

The paper recommends the following if poverty is to be eradicated sincerely and promptly in Gombe State and Nigeria at large. In any poverty eradication policy in Gombe State, judicious use of revenue accrued to the state is necessary vis-à-vis the population especially 
the section identified as poor. There is need for proper projection into the future of population increase when the policy is to be introduced. A good planning is necessary and proper record keeping before a poverty eradication policy is implemented giving specific attention to the future.

For a sincere poverty eradication policy to be on ground, the agencies responsible for data collection should be given a free hand to identify the beneficiaries. Such ministries like Economic Planning, Rural Development, and Bureau of Statistics should be given autonomy to collect data on the targeted population. The outcome should not be tempered for just political or selfish reasons as it happened in the selection of beneficiaries of NAPEP policy in Gombe State.

In order to curb the menace of rising poverty figures in Gombe State, there is need for serious tackling of other issues that are related to poverty or poverty indicators. Efforts should be geared towards provision of quality education and a sound healthcare delivery service. Provision of infrastructure should be given consideration. There is need for the Gombe State Government to borrow from other poverty eradication scheme obtainable in other developing countries. The number of dependents can be catered by a policy scheme like that of Brazilian Bolsa Familia which is a Conditional Cash Transfer.

The government also needs to improve people's income by embarking on serious macro-economic policies that can affect the whole population. There is need to create many jobs, facilitate industrialization, mechanized agriculture, increase the value of currency, promote export of local products, reduce inflation and local company tax and other related issues to boost and improve economic activities that will improve people's income.

\section{References}

Abdullahi, A. (1999). Nigerian Economic Update Problem and the Way Forward. Abuja: FAAC News Publication.

Abdulraheem, T. (2006). "Wealth Creation and Distribution Must Go Hand to Hand". In Weekly Trust, Vol.8 No.20 Abuja: Media Trust Limited.

Academic Staff Union of Nigerian Universities (ASUU) (2009). "World Poverty Indicators 2007, A Communiqué of the National Executive Council" (NEC) Meeting in Weekly Trust Vol.8 No.20 Abuja: Media Trust Limited.

Ajakaiye, O. (2002). "Overview of the Current Poverty Eradication Programmes in Nigeria". In Jega A. M.and Wakili, H. (eds.). The Poverty Eradication Programmes in Nigeria pp.7198. Kano: The Centre for Democratic Research and Training Mambayya House, Bayero University Kano.

Ajegi, S.O. (2002). The Affluence of Poverty. Seminar Paper presented in the Department of Economics. Markurdi: Benue State University.

Ake, C. (1981). A Political Economy of Africa. New York: Longman.

Ake, C. (1996). Democracy and Development in Africa. Washington: Brookings Institution.

Aliyu, S.U.R (2008). "Poverty, Causes Nature and Measurement". In Duze, M.C.

Mohammed, H. \& Kiyawa, I.A. (Eds.) Poverty in Nigeria; Causes, Manifestations and Alleviation Strategies, pp.123-156. London: Adonis and Abbey.

Alkali, R.A. (1996). World Bank and Nigeria; Cornucopia or Pandora's Box. Kaduna: Baraka Press. Anyanwu, J.C. (1997). "Poverty in Nigeria: Concept, Measurements and Determinants". In Poverty Alleviation in Nigeria; selected papers for the 1997 Annual Conference, The Nigerian Economic Society, Nigeria. Ibadan: University of Ibadan. 
Arndt, C. McKay, A. \& Tarp, P. (2016). Growth and Poverty in Sub-Saharan Africa. New York: Oxford University Press.

Arif, G.M. (2006). The Reliability and Credibility of Statistical Data for Poverty Analysis. Asian Development Bank: Background paper series. Project Number: 37717 February 2006.

Atkinson, A.B. (1987). "On the Measurement of Poverty". In Econometrics. 55(4), 749 - 764.

Balkisu, Y.S. (2002. "Democracy and National Unity". In Jega. A.M and Wakili, H. (eds). The leadership question and the Quest for Unity in Nigeria pp. 7-15, Center for Democratic Research and Training, Mambayya house, Bayero University Kano.

Balogun, E.D. (1999). Analyzing Poverty Concept and the Method, Ibadan: The Bullion publication.

Bradshaw, T.K (2006). Theories of Poverty and Anti-poverty Programmes in Community Development RPRC working paper no.0.6-05. Columbia: University of Missouri, Rural Poverty Research Center, February 2006.

Central Bank of Nigeria (2017). Report on Human Development Indicators and Poverty Reduction. Abuja: CBN Bulletin.

Dalhatu, S. (2008). "Repositioning the Local Government for the Poverty Eradication Agenda in Nigeria in Duze, M.C. Mohammed, H. \& Kiyawa, I.A. (eds) Poverty in Nigeria; Causes Manifestation and Alleviation Strategies pp.234-267. London: Adonis and Abbey.

Dandago, K.I. (2008). 'Poverty Alleviation Initiative in Nigeria; LEEMP' as a reassuring alternative Strategies, in Duze, M.C. Mohammed, H. and Kiyawa, I.A. (eds.). Poverty in Nigeria; Causes Manifestations and Alleviation Strategies pp.89-122. London: Adonis and Abbey.

Edoh, T. (2003). "Poverty and Survival of Democracy in Nigeria". Makurdi: Benue State University.

Estache, A. \& Wodon, Q. (2014). Infrastructure and Poverty in Sub-Saharan Africa. New York: Palgrave Macmillan.

Fwatshak, S.U. (2006). "Globalisation and Economic Development in Nigeria; the challenges of poverty reduction through E- commerce". In Ityavyar, D. \& Gundu, Z.A. (Eds.). Globalisation and the challenges of Development in Nigeria: Jos, Nigeria. International Center for Gender and Social Research (INTER- GENDER)

Goldstein, J.S \& Pevehouse, J.C. (2006). International Relations. New York: Priscilla McGraw Hill.

Gombe Jewel in the Savannah (2006). State Economic Empowerment and Development Strategy (SEEDS). Abridged Edition, Gombe State Government 2006.

Haralambos, M. \& Heald, R.M. (1980). Sociology; Themes and perspective. New Delhi: Oxford. Heinz, W. \& Koontz, H. (2005). Management; a Global Perspective. New York: McGraw Hill. Hill, M.S. (1985). The Changing Nature of Poverty, Vol. 479. The welfare State in America; trends and prospect, pp. 31 - 47. Annals of the American Academy of Political and Social Sciences.

Igbuzor, O. (2006). Review of Nigeria Millennium Goals 2005 Report. A review presented at the MDG/GCAP Nigeria Planning Meeting held in Abuja, Nigeria on the 9th March, 2006.

Ijaiya, G.T. (2007). "Poverty Alleviation Programmes". In Amali, S.E. Olawepo, R. (eds.). Nigeria Reform Programme; Issues and Challenges. Ibadan: Vantage publishers limited.

Iredia, T.O. (2004). The place of Nigeria in the Global village 18th convocation ceremony of the university of Maiduguri

Ityavyar, D. \& Gundu, Z.A. (2006). Globalisation and the challenges of Development in Nigeria: Jos, Nigeria. International Center for Gender and Social Research (INTER- GENDER) Jhingan, L.M. (2007). The Economic of Development and Planning. Delhi: Vrinda publication. Kakwenda, M. (2002). Poverty Eradication; where Africa Stand. London: Economic press.

Keynes, J.M. (1992). The General Theory of Employment, Interest and Money, Washington: Prentice Hall Inc. 
Klugman, J. (2002). A source Book for Poverty Reduction Strategies; Macroeconomic and Sectional Approaches, Volume 2. Washington: The World Bank.

Kpakol, M. (2004). National Poverty Eradication Programme; Capacity Acquisition Programmes (CAP) for 2004 in Gombe; a paper presented in NAPEP, Gombe state.

Lawan, M.M. (2004). "The prolonged Military rule and poverty Exacerbation in Nigeria 1984 1994". In Duze, M.C. Mohammed H. \& Kiyawa I.A. (eds.). Poverty in Nigeria; Causes Manifestation and Alleviation Strategies, pp.324-367 London: Adonis and Abbey.

Maduagwu, M.O. \& Onu, V.C. (2006). "Globalisation and National Development in Nigeria". In Ityavyar, D. \& Gundu, Z.A. (Eds.). Globalisation and the challenges of Development in Nigeria: Jos, Nigeria. International Center for Gender and Social Research (Inter- Gender)

Magaji, S. (2005). “The Mystery of Poverty Eradication” in weekly Trust Vol.8 no. 36 Abuja: Media Trust, Limited.

Mahbub Ul Haq (1999). Monitoring Poverty in Asia; Measurement Indicators in Survey Pakistan: Human Development Center.

Maikaba, B. (2008). "The Role of Mass Media in the Fight Against Poverty in Nigeria“. In Duze, M.C. Mohammed, H \& Kiyawa, I.A. (eds), Poverty in Nigeria, Causes, Manifestation and Alleviation Strategies, pp. 111-145. London: Adonis and Abbey.

Malumfashi, S.L. (2008). "The concept of poverty and its various Dimension" in Duze,

M.C. Mohammed, H. \& Kiyawa, I.A. (eds) Poverty in Nigeria; Cause Manifestation and Alleviation Strategies, pp.179-198. London, Adonis and Abbey.

Mansaray, H.E. \& Mansaray Jnr, H.E. (2020). "The Connection between National Culture and Organizational Culture: A Literature Review". Britain International of Humanities and Social Sciences. 2(1), 179-189.

Mbaya, P.Y. (2007). A Handbook of Development Planning Experience and perspective in Nigeria. Maiduguri: Shaffa press limited.

Mukhtar, M. (2008). Poverty Alleviation as Machine for Economic Reconstruction in Nigeria". In Duze, M.C. Mohammed H. \& Kiyawa, I.A. (eds.). Poverty in Nigeria; Cause Manifestations and Alleviation Strategies, pp.276-304 London: Adonis and Abbey.

Myrdal, G. (1974). Asian Drama vol.1 \&2 An Inquiry into the Poverty of Nations. Sweden: Stockholm.

National Poverty Eradication Programmes (NAPEP) (2001). Household Poverty Indicators in Nigeria (1996-2001). Abuja: NAPAP publication.

National Poverty Eradication Programme (NAPEP) (2007). Poverty Indicators in Gombe State. Gombe: NAPEP Office Gombe.

National Poverty Eradication Programme (NAPEP) (2009). Human Poverty Index in Nigeria in 2008. Abuja: NAPEP Publication.

Nda-Isaiah, S. (2007). Nigeria: Full Disclosure selected writings on Governance and state craft May 1999-2004. Abuja: Free Press Limited.

Ndefruh, J. (2007). "Impact of poverty in National Development". in Journal of Globalisation and International Studies. 3(1), 77-98.

Nkrumah, K. (1965). Neo-Colonialism: the last Stage of Imperialism. London: Thomas Nelson and sons limited.

Nurkse, R. (1967). Problems of Capital Formation in Underdeveloped Countries and Patterns of Trade and Development. New York: Oxford University press.

Nwagbara, E.N. (2006). "The Globalization phenomenon and the increasing Rate of Poverty in Africa; toward a cautions Response". In Ityavyar, D. \& Gundu, Z.A. (Eds.). Globalisation and the challenges of Development in Nigeria: Jos, Nigeria. International Center for Gender and Social Research (INTER- GENDER)

Odusola, A.F. (1997). "Poverty in Nigeria; An Eclectic Appraisal". in Poverty Alleviation in Nigeria, selected papers for the 1997 Annual Conference, the Nigerian Economic Society (1997). Ibadan: University of Ibadan.

Offiong, D.A. (1980). Imperialism and Dependency. Onitsha: Fourth Dimension publishers Nigeria. 
Ogwumike, F.O. (1991). "A Basic Needs-Oriented Approach to the Measurement of poverty". In Nigerian Journal of Economic and Social Studies 2(33), 91-108.

Okongwu, C.S.P. (2002). The Nigerian Economy; Anatomy of A Traumatized Economy with some proposals for Stabilisation. Enugu: Fourth Dimension publishers.

Okupe, D.C. (2002). Nigeria; An Anthology for National Rebirth. Abuja: Essence Communication Limited.

Onimode, B. (1983). Imperialism and underdevelopment in Nigeria. Ibadan: Macmillan.

Onwuka, E.C. (2006). "Globalisation and NEPAD Revisited in the Light of Nigerian Experience". In Ityavyar, D. and Gundu, Z.A. (eds.) NEPAD and challenges of Development in Nigeria, Jos: International Center for Gender and Social Research (INTER- GENDER), Nigeria.

Orji, J.T. (2008). New Approaches to Effective Poverty Alleviation in Nigeria. Kaduna: Joyce Graphic.

Popovic, R. Samouilidou, E. Popovic, J. \& Dolga, M. (2020). "Assessment of the Quality of Life, Health, and Social Wellness in Upper Elementary School Students: Cross-Cultural and Gender Specificity". Britain International of Humanities and Social Sciences. 2(1), 127-142.

Sachs, J.D. (2015) The End of Poverty: Economic Possibilities for Our Time. New York: Penguin Press.

Sagagi, S.M. (2008). "The Nigeria Government and War Against Poverty" in Duze, M.C. Mohammed, H. \& Kiyawa, I.A (eds.). Poverty in Nigeria; Causes Manifestation and Alleviation Strategies, pp. 369-401. London: Adonis and Abbey.

Schelzig, K. (2004). "Poverty Reduction; the Measurement Question". In Mudacumura, G.M. \& Shamsul Hague, M. (Eds.). Public Administration and Public Policy, Handbook of Development policy Studies, pp. 17-29. USA: Marcel Dekker, Inc.

Sen, A. (1997). Concept of Human Development and Poverty; A Multidimensional Perspective. Delhi: S. Chand.

Smith, A. (1759). An Inquiry into the Wealth of Nations. London: Oxford.

Solow, R.M. (1976). Poverty and Economic Growth. USA: Massachusetts Institute of Technology.

Somasundara, D. (2010). Professor Dayawanda Somasundara Felicitation Ceremony 2010 to appreciate the forty years (40) of service to the Field of Education, Sri Lanka.

Sule, B. Adamu, U. \& Yahaya, M.A. (2019). "National Poverty Eradication Programme (NAPEP) in Nigeria: A Case of Capacity Acquisition Programme (CAP) in Gombe State". Journal of Public Administration and Governance. 9(2), 230-247.

Sule, B. \& Adamu, U. (2019). "National Poverty Eradication Programme (NAPEP): A Critical Analysis". In Jigawa Journal of Politics. 2(1), 188-211.

The National Bureau of Statistics (2005). The Nigeria Statistical Fact Sheets on Economic and Social Development. Abuja: NBS.

The National Bureau of Statistics (2017). Human Poverty Index in Nigeria. Abuja: NBS Report. The World Bank (2007). World Development Indicators. Washington D.C: World Bank.

The World Bank (2007). World Development Report; Development and the next Generation. Washington D.C.: World Bank.

Udegbunam, C. (2006). Graduate Unemployment in Nigeria; A Critical Analysis of the Genesis. Abuja: Essence press.

United Nations Development Programme (2008). Human Development Report; Nigeria 2008 - 2009. Achieving Growth with Equity. UN House Garki Abuja, Nigeria.

United Nations Family Planning Affairs (2006). Report on Integrated Survey of Household in selected Enumerated Areas of Gombe State. Washington: United Nation.

United Nations Development Report (2017). Human Development Report 2017. Washington: United Nations.

Usman, Y.B. (1979). For the Liberation of Nigeria. London: New Beacon Books.

Yakubu, M. (2009). Lance on Skill Acquisition to Unemployed Youth Wing of Christian Association of Nigeria (YOWICAN) Gombe State chapter; A paper presentation by State Co-ordinator (NAPEP), 11 September, 2009. 